\section{Resistance to Infection by Fungal, Bacterial, and Viral Pathogens in a Common Bean Core Collection from the Iberian Peninsula}

\author{
Ana B. Monteagudo, A. Paula Rodiño, Margarita Lema, María De la \\ Fuente, Marta Santalla, and Antonio M. De Ron ${ }^{1}$ \\ Plant Genetic Resources Department, Misión Biológica de Galicia (MBG- \\ CSIC), P.O. Box 28, 36080 Pontevedra, Spain
}

\author{
Shree P. Singh \\ University of Idaho, Kimberly Research and Extension Center, 3793 North 3600 \\ East, Kimberly, Idaho 83341-5076, U.S.A. Published as Idaho Agricultural \\ Experiment Station Journal Article No. 04712, University of Idaho, College \\ of Agriculture, Moscow, ID 83844 \\ Additional index words. disease resistance, genetic improvement, genetic resources, \\ landrace, Phaseolus vulgaris
}

\begin{abstract}
Availability of germplasm with high level of resistance is essential for broadening the genetic base and breeding crop cultivars resistant to abiotic and biotic stresses. The objective of this study was to determine reaction of a common bean core collection from the Iberian Peninsula to anthracnose, rust, common and halo blights, bean common mosaic virus (BCMV, a potyvirus) and bean common mosaic necrosis virus (BCMNV, a potyvirus) pathogens. Of 43 accessions evaluated, 14 large-seeded Andean type, seven small-seeded Middle American type and seven with intermediate characteristics or recombinant type between the two gene pools had resistant reaction to one or more diseases. Resistance to race 17 or 23 of anthracnose pathogen was present in 17 accessions and four accessions were resistant to both races. Resistance to race 38 or 53 of rust pathogen was shown by 22 accessions and five accessions were resistant to both races. All accessions were susceptible to common bacterial blight and 12 accessions had resistance to halo blight. Ten accessions showed resistance to $\mathrm{BCMV}$, none to $\mathrm{BCMNV}$, and two were variable to both viruses. Accessions such as PHA-0573 (pinto), PHA-0589 (marrow), PHA-0654 (favada pinto), and PHA-0706 (favada) showed resistance to two or more diseases. These accessions may be valuable in breeding Andean bean for enhancing simultaneous utilization of both large seed size and disease resistance.
\end{abstract}

Consumption of dry and green bean (Phaseolus vulgaris L.) has been increasing steadily in some developed countries (e.g., U.S.) in recent years because of associated health benefits (Willet et al., 1995), the availability of diversified processed food products in market and demographic changes. In many areas of Spain and Portugal, beans are very popular as a part of traditional recipes. Beans are grown on small farms for home consumption but recently the demand for traditional or heirloom

\footnotetext{
Received for publication 17 Oct. 2005. Accepted for publication $10 \mathrm{Jan}$. 2006. This research was supported by the projects PGIDIT03PXIC40301PN and RTA03-048-C2-2 from the Galician and Spanish Governments and by fellowships from the Galician Government and the University of Santiago de Compostela to Ana B. Monteagudo. We are also grateful to the CRF-INIA(Alcalá de Henares, Spain) for supplying seeds of some common bean accessions, the University of Idaho and Seminis Vegetable Seeds Co. for greenhouse and laboratory facilities for disease evaluations and to Carl Strausbaugh, Stephen Love and Krishna Mohan for reviewing the manuscript.

${ }^{1}$ To whom reprint requests should be addressed; e-mail amderon@mbg.cesga.es.
}

[caused by Xanthomonas axonopodis pv. phaseoli (Smith) Dye], halo blight (HB) [caused by Pseudomonas syringae pv. phaseolicola (Burkh.)], bean common mosaic virus (BCMV, a potyvirus), and bean common mosaic necrosis virus (BCMNV, a potyvirus). Some pathogen including those causing ANT (Pastor-Corrales et al., 1995) and rust (Sandlin et al., 1999) have co-evolved with common bean forming distinct Andean (A) and Middle American (MA) populations. Pathogens causing ANT, CBB, $\mathrm{HB}, \mathrm{BCMV}$, and BCMNV are seed-borne, may survive in crop debris over a prolonged period, and are disseminated mechanically, by insect vectors, rains, and/or winds. Thus, their chemical control is often difficult and increases production costs for bean growers.

Disease resistance tends to concentrate in germplasm from specific areas, therefore, a core collection facilitates the identification of the geographic distribution of favourable genes imparting resistance to major diseases (Simon and Hannan, 1995). The common bean germplasm collection from the Iberian Peninsula at the MBG-CSIC comprises 430 accessions, of which 52 form part of a core collection (Rodiño et al., 2003). The entire collection and the core include some recombinant or intermediate types (Santalla et al., 2002) that may be of interest for local and worldwide breeding as potential parents for inter-gene pool transfer of favorable genes in common bean. Reaction of the core collection to the diseases listed above are not known. Therefore, the primary objective of this research was to evaluate the reaction of the core collection to ANT, rust, $\mathrm{CBB}, \mathrm{HB}, \mathrm{BCMV}$, and BCMNV.

\section{Materials and Methods}

The common bean core collection from the Iberian Peninsula maintained at MBG-CSIC (Pontevedra, Spain) (Rodiño et al., 2003) was evaluated for reaction to $\mathrm{ANT}$, rust, $\mathrm{CBB}, \mathrm{HB}$, $\mathrm{BCMV}$, and $\mathrm{BCMNV}$ in separate nurseries in the greenhouse at Filer and Kimberly, Idaho, U.S.A. in 2002. Accessions from the core collection were landraces representing the different markets classes widely grown in the Iberian Peninsula. These accessions belong either to the A and the MA gene pools of common bean being some of them intermediate or recombinant forms among these pools (Santalla et al., 2002). In addition, nine breeding lines or cultivars with different agronomic characteristics and seed types were used as susceptible or resistant controls (Table 1). Six plants per accession were inoculated for each disease evaluation. Each plant was considered a separate replicate. Due to the genetic origin of the accessions (A, MA and intermediate), ANT and rust inoculations were conducted with races of the pathogens that originated in the two centers of origin of the common bean.

Anthracnose. Four plants per accession were inoculated with a Middle American race 17 and two with an Andean race 23 of $C$. lindemuthianum. The isolates were cultured on potato dextrose agar (PDA) medium and incubated at $20^{\circ} \mathrm{C}$ for 5 to $10 \mathrm{~d}$ in dark (Monteagudo, 2004). The spore concentration was 
Table 1. Market class, seed size, growth habit and disease reaction to anthracnose (ANT), rust, common bacterial blight (CBB), halo blight (HB), bean common mosaic virus (BCMV) and bean common mosaic necrosis virus (BCMNV) of nine common bean genotypes.

\begin{tabular}{|c|c|c|c|c|c|c|c|c|c|c|c|}
\hline \multirow[b]{2}{*}{ Genotypes } & \multirow[b]{2}{*}{ Market class } & \multirow{2}{*}{$\begin{array}{l}\text { Seed } \\
\text { size }^{z}\end{array}$} & \multirow{2}{*}{$\begin{array}{l}\text { Growth } \\
\text { habit }^{y}\end{array}$} & \multicolumn{2}{|c|}{$\mathrm{ANT}^{x}$} & \multicolumn{2}{|c|}{ Rust $^{w}$} & \multirow[b]{2}{*}{$\mathrm{CBB}^{v}$} & \multirow[b]{2}{*}{$\mathrm{HB}^{v}$} & \multirow[b]{2}{*}{$\mathrm{BCMV}^{u}$} & \multirow[b]{2}{*}{$\mathrm{BCMNV}^{\iota}$} \\
\hline & & & & 17 & 23 & 38 & $\overline{53}$ & & & & \\
\hline $\mathrm{A} 483$ & Red pinto & $\mathrm{L}$ & IV & $\mathrm{R}$ & $\mathrm{S}$ & $\mathrm{R}$ & $\mathrm{P}$ & 9 & 9 & $\mathrm{R}$ & $\mathrm{N}$ \\
\hline Chase & Pinto & M & III & $\mathrm{S}$ & $\mathrm{S}$ & $\mathrm{R}$ & $\mathrm{N}$ & 3 & 4 & $\mathrm{~S}$ & $\mathrm{~S}$ \\
\hline Common Pinto & Pinto & M & III & $\mathrm{S}$ & $\mathrm{S}$ & $\mathrm{R}$ & $\mathrm{S}$ & 9 & 7 & $\mathrm{~S}$ & $\mathrm{~S}$ \\
\hline Kodiak & Pinto & M & III & $\mathrm{S}$ & $\mathrm{S}$ & $\mathrm{R}$ & $\mathrm{P}$ & 9 & 7 & $\mathrm{R}$ & $\mathrm{LN}$ \\
\hline Matterhorn & Great northern & M & II & $\mathrm{S}$ & $\mathrm{S}$ & $\mathrm{R}$ & $\mathrm{P}$ & 7 & 6 & $\mathrm{R}$ & $\mathrm{N}$ \\
\hline Montrose & Pinto & M & III & $\mathrm{S}$ & $\mathrm{S}$ & $\mathrm{R}$ & $\mathrm{R}$ & 7 & 8 & $\mathrm{~S}$ & $\mathrm{~S}$ \\
\hline Othello & Pinto & M & III & $\mathrm{S}$ & $\mathrm{S}$ & $\mathrm{S}$ & $\mathrm{S}$ & 9 & 6 & $\mathrm{~S}$ & $\mathrm{~S}$ \\
\hline USPT-ANT-1 & Pinto & M & III & $\mathrm{R}$ & $\mathrm{R}$ & $\mathrm{R}$ & $\mathrm{P}$ & 8 & 6 & $\mathrm{R}$ & $\mathrm{N}$ \\
\hline VAX 3 & Small red & $\mathrm{S}$ & II & $\mathrm{S}$ & $\mathrm{S}$ & $\mathrm{R}$ & $\mathrm{S}$ & 3 & 7 & $\mathrm{R}$ & $\mathrm{N}$ \\
\hline
\end{tabular}

zSeed size (hence weight): $\mathrm{S}=$ small, $<25 \mathrm{~g} / 100$ seeds; $\mathrm{M}=$ medium, 25 to $40 \mathrm{~g} / 100$ seeds; and $\mathrm{L}=1$ large, $>40 \mathrm{~g} / 100 \mathrm{seeds}$.

${ }^{y_{\mathrm{I}}}=$ determinate upright, $\mathrm{II}=$ indeterminate upright, $\mathrm{III}=$ indeterminate prostrate and $\mathrm{IV}=$ indeterminate strong climbing.

${ }^{\mathrm{x}} \mathrm{S}=$ susceptible (extended lesions), $\mathrm{R}=$ resistant (without symptoms).

${ }^{\text {w }} \mathrm{S}=$ susceptible (large pustules), $\mathrm{P}=$ small pustules, $\mathrm{N}=$ necrotic pustules, $\mathrm{R}=$ resistant (without symptoms).

${ }^{v}$ Scale from 1 (without symptoms) to 9 (extended lesions), where scores $<4=$ resistant, 4 to $6=$ intermediate, and $>6=$ susceptible.

u $\mathrm{S}=$ susceptible (common mosaic symptoms), $\mathrm{R}=$ resistant (without symptoms), $\mathrm{N}=$ top necrosis, $\mathrm{LN}=$ local and venal necrosis.

adjusted to $10^{6}$ conidia/mL. Fully expanded primary leaves were sprayed with the conidia suspension (Geissen and Steenbergen, 1957), using a hand-held spray bottle. Inoculated plants were covered with a plastic bag for 24 $\mathrm{h}$ to increase humidity. Inoculated plants were placed on a table in the greenhouse with 15.5 ${ }^{\circ} \mathrm{C}$ minimum and $24^{\circ} \mathrm{C}$ maximum temperatures and $65 \%$ humidity. Ten days after inoculation plants were rated into the following three groups: susceptible, characterized by darkening of veins followed by inter-venal lesions on the lower leaf surface and seedling death; intermediate, plants with only minor venal lesions; and resistant, without any disease symptoms.

Rust. Urediniospores were multiplied in cultivars Acclaim for an Andean race 38 and Olathe for a Middle American race 53 of $U$. appendiculatus. The urediniospores were suspended in distilled water in a $20 \mu \mathrm{g} \cdot \mathrm{mL}^{-1}$ concentration adding $40 \mu \mathrm{L} \cdot \mathrm{L}^{-1}$ of Tween- 20 . The abaxial surface of the fully expanded primary leaves of six plants per accession was inoculated. One primary leaf of each plant was inoculated with race 38 and the other with race 53 , using the spray-inoculation technique (Stavely, 1983). Inoculated plants were covered with a plastic bag for $24 \mathrm{~h}$ to increase humidity and facilitate germination of urediniospores. Three weeks after inoculation the following reactions were recorded: resistant $(\mathrm{R})$, no visible rust symptoms; necrotic pustules $(\mathrm{N})$, presence of very small nonsporulating pustules; small pustules $(\mathrm{P})$, presence of very small (uredinia less than $0.3 \mathrm{~mm}$ in diameter) sporulating pustules, and susceptible(S), presence of large (uredinia larger than $0.3 \mathrm{~mm}$ in diameter) profusely sporulating pustules.

Common bacterial blight. Bacterial culture was grown in a yeast-dextrose calcium carbonate agar (YDCA) medium for $48 \mathrm{~h}$. A bacterial concentration of $1 \times 10^{7}$ colony-forming units (cfu) $/ \mathrm{ml}$ was used to inoculate both primary leaves of six plants per accession. A small florist's frog (i.e., $>12$ needles pinned on to a $<3 \mathrm{~cm}$ diameter round metallic block) was used for bacterial inoculation (Singh and Muñoz, 1999). The process was repeated $10 \mathrm{~d}$ later on the first trifoliolate leaf. Ten and $14 \mathrm{~d}$ after each inoculation disease evaluations were made on a 1 to 9 disease severity scale, where $1=$ no visible symptoms, and $9=$ severely diseased (Schoonhoven and Pastor-Corrales, 1987). But, the data was included only for the 10th day because all accessions had a score of 9 (severely diseased) at the latter date.

Halo blight. The Hbr2 and $J C H B$ variants of the most widely distributed and highly pathogenic race 2 (similar to race 6) of P. syringae pv. phaseolicola were grown in the King's medium $\mathrm{B}$ for $24 \mathrm{~h}$ at room temperature. By using a mix of the two variants, a bacterial concentration of $1 \times 10^{7} \mathrm{cfu} / \mathrm{mL}$ was prepared for inoculation. The lower sides of newly opened expanding (6 to $7 \mathrm{~d}$ after sowing) both primary leaves of six plants per accession were inoculated using multiple-needles. The rating scale for leaf reaction $7 \mathrm{~d}$ after inoculation was from $1=$ no visible symptoms to $9=$ severely diseased (Schoonhoven and Pastor-Corrales, 1987). In both bacterial blight cases, the reaction to pathogens was classified into three categories: scores $\leq 3=$ resistant, 4 to $6=$ intermediate, and $\geq 7$ = susceptible.

$B C M V$. Fresh inoculum of the US-6 strain of BCMV was maintained on 'Dubbele Witte' plants. A triturate of infected leaves was prepared using the procedure described by Strausbaugh et al. (1999). One primary leaf per plant was inoculated using sterile cotton Q-tips 7 to $10 \mathrm{~d}$ after sowing. All plants were evaluated $21 \mathrm{~d}$ after inoculation according to the presence or absence of the following symptoms: resistant (R), no visible disease symptoms; or susceptible (S), with light and dark green mosaic symptoms, reduced leaf size and plant height, and leaf curling or other deformities.

$B C M N V$. The fresh inoculum of the NL-3K strain of BCMNV was maintained on pinto cultivar Ouray. The inoculation method was similar to the above described for BCMV (Strausbaugh et al., 1999). Plants were evaluated $21 \mathrm{~d}$ after inoculation as resistant (R), no visible disease symptoms; susceptible (S), with light and dark green mosaic symptoms, reduced leaf size and plant height, and leaf curling or other deformities; local necrosis (N), small pin-point necrotic lesion; and top necrosis $(\mathrm{T})$, local and venal necrosis follow by death starting from the apex of plant.

Average score for the reaction of $\mathrm{CBB}$ and $\mathrm{HB}$ were recorded for each accession. Data for
$\mathrm{CBB}$ and $\mathrm{HB}$ were analyzed using a general lineal model (GLM) procedure (SAS Inst., Cary, N.C.), and mean and LSD $(P<0.05)$ values were calculated for each disease.

\section{Results and Discussion}

Of nine breeding lines or cultivars used as susceptible or resistant controls, A483 was resistant to the MA race 17 of $C$. lindemuthianum but susceptible to the A race 23, whereas USPT-ANT-1 was resistant to both races (Table 1). Both breeding lines were resistant to BCMV but exhibited top necrosis to $\mathrm{BCMNV}$ hence indicating that they carried the dominant $I$ gene for BCMV resistance (Drijfhout 1978). Pinto cultivar Chase had an intermediate or resistance reaction to $\mathrm{CBB}$, $\mathrm{HB}$, and both races of the rust pathogen. A similar reaction to the rust pathogens was also observed for Kodiak, Matterhorn, Montrose, and USPT-ANT-1. No breeding line or cultivar used as control was susceptible to all diseases and pathogen races.

Of 43 accessions from the core collection 25 were of the A origin, nine of the MA origin and nine were recombinant types (Table 2) (Santalla et al., 2002). Seventeen accessions had white seed and 31 had an indeterminate growth habit. Furthermore, only three accessions were susceptible to all diseases and pathogen races. Thus, either a higher proportion of resistant accessions were inadvertently introduced from the Americas initially, or else the environments, pathogen pressure, and human interference in the Iberian Peninsula were conducive for subsequent increase of resistance alleles. Limited evidence at hand may suggest that the latter was more likely the case. For example, some accessions that exhibited a variable reaction to one or more diseases were mixtures of genotypes adapted to local environments. Out-crosses may occasionally have occurred between different genotypes within accession because of their close proximity and visits from pollinating insects, giving an opportunity for selection of genotypes combining resistance to one or more diseases. This phenomenon might have lead to the evolution of accessions with tolerance and/or resistance to different pathogens. Some of them are the A types such as PHA-0086 
(canellini), PHA-0274 (dark garbanzo), PHA0303 (large cranberry), PHA-0345 (canela), PHA-0390 (brown mottled), PHA-0521 (dark red kidney), PHA-0577 (large cranberry), PHA-0654 (favada pinto), and PHA-0706 (favada). Ome were the MA types such as PHA-0247 (black turtle), PHA-0471 (navy), PHA-0573 (pinto), and PHA-0663 (mulatihno), while others were the recombinants such as accessions PHA-0399 (large great northern), PHA-0523 (small white), PHA-0589 (marrow) and PHA-0917 (favada).

There is some evidence that secondary diversification of $P$. vulgaris occurred from inter-gene pool crosses producing recombinant forms in the Iberian Peninsula (Santalla et al., 2002). Thus, the recombinant accessions may provide resistance to a much broader range of pathogen populations and to multiple diseases.
In general, disease resistant accessions did not follow any specific pattern of geographical distribution. Nonetheless, accessions resistant to HB seemed to be concentrated in Galicia, a region from which all accessions were susceptible to BCMV and BCMNV.

Five accessions were either resistant or intermediate to ANT pathogen race 17 and 20 accessions to race 23 (Table 2). However, as could be expected, only one of the MA type accession was resistant to the MA pathogen race 17 possibly because of the host-pathogen co-evolution, and the fact that the MA pathogen races often are more virulent than their $\mathrm{A}$ counterparts (Pastor-Corrales et al., 1995). In contrast, 13 large-seeded A types were either resistant or intermediate to the race 23 of which the most valuable were PHA-0086 (canellini), PHA-0303 (large cranberry) and PHA-0521 (dark red kidney) because they were also resistant to the race 17. The accession PHA0706 from Asturias with resistance to race 23 is also of mention because of its extra-large white seed (favada market class) that is highly sought after especially in northern Spain (Ferreira et al., 2003).

Anthracnose was a major constraint to both dry and snap bean production in Europe until the 1960's. However, by using resistant cultivars and pathogen-free seed the disease has been effectively controlled in snap bean, especially in France and the Netherlands. In contrast, anthracnose continues to be severe in northern Spain (e.g., Asturias and Castilla y León) where cultivation of highly susceptible dry bean cultivars still predominates. Thus, it should be worth investigating which resistance gene(s) is present in each of the accessions

Table 2. Origin and genetic pool, market class, seed size, growth habit and reactions to anthracnose (ANT), rust, common bacterial blight (CBB), halo blight (HB), bean common mosaic virus (BCMV) and bean common mosaic necrosis virus (BCMNV) of the accessions of an Iberian common bean core collection.

\begin{tabular}{|c|c|c|c|c|c|c|c|c|c|c|c|c|}
\hline \multirow[b]{2}{*}{ Accession } & \multirow[b]{2}{*}{ Origin/genetic pool ${ }^{z}$} & \multirow[b]{2}{*}{ Market class } & \multirow{2}{*}{$\begin{array}{l}\text { Seed } \\
\text { size }^{y}\end{array}$} & \multirow{2}{*}{$\begin{array}{l}\text { Growth } \\
\text { habit }^{x}\end{array}$} & \multicolumn{2}{|c|}{$\mathrm{ANT}^{w}$} & \multicolumn{2}{|c|}{ Rust $^{v}$} & \multirow[b]{2}{*}{$\mathrm{CBB}^{u}$} & \multirow[b]{2}{*}{$\mathrm{HB}^{u}$} & \multirow{2}{*}{\multicolumn{2}{|c|}{$\mathrm{BCMV}^{t} \mathrm{BCMNV}^{t}$}} \\
\hline & & & & & 17 & 23 & 38 & 53 & & & & \\
\hline$\overline{\mathrm{PHA}-0036}$ & Bragança, P (A) & Marrow & $\mathrm{M}$ & II & $\mathrm{S}$ & $\mathrm{S}$ & $\mathrm{S}$ & $\mathrm{P}$ & 9.0 & 7.8 & $\mathrm{R}$ & $\mathrm{N}$ \\
\hline PHA-0037 & Bragança, P (MA) & Great northern & $\mathrm{L}$ & I & $\mathrm{S}$ & $\mathrm{V}$ & $\mathrm{S}$ & $\mathrm{P}$ & 8.7 & 7.4 & $\mathrm{~S}$ & $\mathrm{~S}$ \\
\hline PHA-0062 & Bragança, P (A) & White kidney & $\mathrm{L}$ & III & $\mathrm{S}$ & I & $\mathrm{S}$ & $\mathrm{P}$ & 8.7 & 8.3 & $\mathrm{~S}$ & $\mathrm{~S}$ \\
\hline PHA-0065 & Bragança, P (I) & Small white & M & II & $\mathrm{S}$ & $\mathrm{S}$ & $\mathrm{R}$ & $\mathrm{S}$ & 8.5 & 5.6 & $\mathrm{~S}$ & $\mathrm{~S}$ \\
\hline PHA-0081 & Bragança, P (A) & Cranberry & $\mathrm{L}$ & III & $\mathrm{S}$ & $\mathrm{S}$ & $\mathrm{S}$ & $\mathrm{S}$ & 9.0 & 5.7 & $\mathrm{~S}$ & $\mathrm{~S}$ \\
\hline PHA-0086 & Bragança, P (A) & Canellini & $\mathrm{L}$ & $\mathrm{I}$ & $\mathrm{R}$ & $\mathrm{R}$ & $\mathrm{P}$ & $\mathrm{P}$ & 9.0 & 7.7 & $\mathrm{~S}$ & $\mathrm{~S}$ \\
\hline PHA-0105 & Bragança, P(A) & Canela & $\mathrm{L}$ & II & $\mathrm{S}$ & $\mathrm{I}$ & $\mathrm{S}$ & $\mathrm{V}$ & 8.8 & 6.2 & $\mathrm{~S}$ & $\mathrm{~S}$ \\
\hline PHA-0107 & Bragança, P (I) & Small white & M & IV & $\mathrm{S}$ & $\mathrm{S}$ & $\mathrm{R}$ & $\mathrm{S}$ & 8.7 & 7.7 & $\mathrm{~S}$ & $\mathrm{~S}$ \\
\hline PHA-0215 & Galicia, S (I) & Bayo gordo & $\mathrm{L}$ & IV & $\mathrm{S}$ & $\mathrm{R}$ & $\mathrm{S}$ & $\mathrm{S}$ & 8.7 & 5.2 & $\mathrm{~S}$ & $\mathrm{~S}$ \\
\hline PHA-0225 & Galicia, S (A) & Marrow & $\mathrm{L}$ & IV & $\mathrm{S}$ & $\mathrm{R}$ & $\mathrm{S}$ & $\mathrm{S}$ & 8.8 & 8.0 & $\mathrm{~S}$ & $\mathrm{~S}$ \\
\hline PHA-0247 & Asturias, S (MA) & Black turtle & $\mathrm{S}$ & IV & $\mathrm{S}$ & $\mathrm{V}$ & $\mathrm{P}$ & $\mathrm{V}$ & 8.8 & 3.3 & $\mathrm{R}$ & $\mathrm{N}$ \\
\hline PHA-0252 & Galicia, S (A) & Canellini & M & IV & $\mathrm{S}$ & $\mathrm{S}$ & $\mathrm{R}$ & $\mathrm{S}$ & 9.0 & 7.2 & $\mathrm{~S}$ & $\mathrm{~S}$ \\
\hline PHA-0273 & Galicia, S (MA) & Great northern & M & IV & $\mathrm{S}$ & $\mathrm{S}$ & $\mathrm{R}$ & $\mathrm{S}$ & 8.7 & 7.3 & $\mathrm{~S}$ & $\mathrm{~S}$ \\
\hline PHA-0274 & Galicia, S (A) & Dark garbanzo & M & IV & $\mathrm{S}$ & V & $\mathrm{S}$ & $\mathrm{S}$ & 9.0 & 5.5 & V & $\mathrm{V}$ \\
\hline PHA-0279 & Galicia, S (A) & Cranberry & $\mathrm{L}$ & IV & $\mathrm{S}$ & $\mathrm{V}$ & $\mathrm{S}$ & $\mathrm{S}$ & 8.7 & 7.5 & $\mathrm{~S}$ & $\mathrm{~S}$ \\
\hline PHA-0303 & Galicia, S (A) & Large cranberry & $\mathrm{L}$ & IV & $\mathrm{R}$ & $\mathrm{R}$ & $\mathrm{S}$ & $\mathrm{P}$ & 8.8 & 6.4 & $\mathrm{~S}$ & $\mathrm{~S}$ \\
\hline PHA-0345 & Galicia, S (A) & Canela & $\mathrm{L}$ & I & $\mathrm{S}$ & $\mathrm{R}$ & $\mathrm{S}$ & $\mathrm{V}$ & 8.8 & 8.0 & $\mathrm{~S}$ & $\mathrm{~S}$ \\
\hline PHA-0390 & Galicia, S (A) & Brown mottled & $\mathrm{L}$ & IV & $\mathrm{S}$ & $\mathrm{I}$ & $\mathrm{P}$ & $\mathrm{S}$ & 8.8 & 5.4 & $\mathrm{~S}$ & $\mathrm{~S}$ \\
\hline PHA-0399 & Asturias, S (I) & Large great northern & $\mathrm{L}$ & IV & $\mathrm{S}$ & $\mathrm{I}$ & $\mathrm{R}$ & $\mathrm{S}$ & 9.0 & 5.0 & $\mathrm{~S}$ & $\mathrm{~S}$ \\
\hline PHA-0407 & Asturias, S (A) & Sangretoro & M & IV & $\mathrm{S}$ & $\mathrm{S}$ & $\mathrm{S}$ & $\mathrm{S}$ & 9.0 & 7.5 & $\mathrm{~S}$ & $\mathrm{~S}$ \\
\hline PHA-0414 & Asturias, S (I) & Small yellow & M & I & $\mathrm{S}$ & V & $\mathrm{S}$ & $\mathrm{S}$ & 8.8 & 7.5 & $\mathrm{~S}$ & $\mathrm{~S}$ \\
\hline PHA-0448 & Navarra, S (A) & Negro brillante & M & IV & $\mathrm{S}$ & $\mathrm{S}$ & $\mathrm{P}$ & $\mathrm{P}$ & 8.7 & 5.7 & $\mathrm{R}$ & $\mathrm{N}$ \\
\hline PHA-0470 & Asturias, S (A) & Dark garbanzo & $\mathrm{S}$ & I & $\mathrm{S}$ & $\mathrm{S}$ & $\mathrm{S}$ & $\mathrm{P}$ & 9.0 & 6.7 & $\mathrm{~S}$ & $\mathrm{~S}$ \\
\hline PHA-0471 & Asturias, S (MA) & Navy & $\mathrm{S}$ & I & I & $\mathrm{S}$ & $\mathrm{N}$ & $\mathrm{N}$ & 8.5 & 7.0 & $\mathrm{R}$ & $\mathrm{N}$ \\
\hline PHA-0476 & Asturias, S (A) & Hen eye & M & IV & $\mathrm{S}$ & $\mathrm{S}$ & $\mathrm{S}$ & $\mathrm{S}$ & 9.0 & 6.0 & $\mathrm{R}$ & $\mathrm{N}$ \\
\hline PHA-0501 & País Vasco, S (I) & Negro brillante & $\mathrm{L}$ & IV & $\mathrm{S}$ & $\mathrm{S}$ & $\mathrm{S}$ & $\mathrm{P}$ & 9.0 & 5.3 & $\mathrm{R}$ & $\mathrm{N}$ \\
\hline PHA-0521 & Castilla y León, S (A) & Dark red kidney & $\mathrm{L}$ & $\mathrm{I}$ & $\mathrm{R}$ & $\mathrm{R}$ & $\mathrm{P}$ & $\mathrm{S}$ & 8.8 & 7.5 & $\mathrm{~S}$ & $\mathrm{~S}$ \\
\hline PHA-0523 & Castilla y León, S (I) & Small white & $\mathrm{S}$ & II & $\mathrm{S}$ & $\mathrm{I}$ & $\mathrm{R}$ & $\mathrm{S}$ & 7.8 & 5.2 & $\mathrm{~S}$ & $\mathrm{~S}$ \\
\hline PHA-0552 & Castilla y León, S (A) & Large cranberry & $\mathrm{L}$ & II & $\mathrm{S}$ & $\mathrm{R}$ & $\mathrm{S}$ & $\mathrm{S}$ & 8.7 & 6.2 & $\mathrm{~S}$ & $\mathrm{~S}$ \\
\hline PHA-0563 & Castilla y León, S (A) & Canellini & $\mathrm{L}$ & $\mathrm{I}$ & $\mathrm{S}$ & $\mathrm{I}$ & $\mathrm{S}$ & $\mathrm{S}$ & 9.0 & 8.4 & $\mathrm{~S}$ & $\mathrm{~S}$ \\
\hline PHA-0565 & La Rioja, S (A) & Red caparron & M & IV & $\mathrm{S}$ & $\mathrm{S}$ & $\mathrm{S}$ & $\mathrm{S}$ & 9.0 & 7.2 & $\mathrm{R}$ & $\mathrm{N}$ \\
\hline PHA-0573 & Castilla y León, S (MA) & Pinto & M & IV & $\mathrm{S}$ & $\mathrm{S}$ & $\mathrm{R}$ & $\mathrm{S}$ & 9.0 & 7.0 & $\mathrm{~V}$ & $\mathrm{~V}$ \\
\hline PHA-0577 & Valencia, S (A) & Large cranberry & M & $\mathrm{I}$ & $\mathrm{V}$ & $\mathrm{R}$ & $\mathrm{S}$ & $\mathrm{P}$ & 8.7 & 9.0 & $\mathrm{~S}$ & $\mathrm{~S}$ \\
\hline PHA-0587 & Castilla y León, S (MA) & Great northern & M & IV & $\mathrm{S}$ & $\mathrm{S}$ & $\mathrm{R}$ & $\mathrm{S}$ & 9.0 & 7.7 & $\mathrm{~S}$ & $\mathrm{~S}$ \\
\hline PHA-0589 & Castilla y León, S (I) & Marrow & $\mathrm{L}$ & I & $\mathrm{S}$ & $\mathrm{S}$ & $\mathrm{S}$ & $\mathrm{R}$ & 9.0 & 8.0 & $\mathrm{R}$ & $\mathrm{N}$ \\
\hline PHA-0590 & Castilla y León, S (A) & Red pinto & M & II & $\mathrm{S}$ & $\mathrm{V}$ & $\mathrm{S}$ & $\mathrm{S}$ & 8.5 & 8.0 & $\mathrm{~S}$ & $\mathrm{~S}$ \\
\hline PHA-0632 & Aragón, S (MA) & Chumbinho & M & IV & $\mathrm{S}$ & $\mathrm{S}$ & $\mathrm{R}$ & $\mathrm{S}$ & 8.2 & 6.3 & $\mathrm{R}$ & $\mathrm{N}$ \\
\hline PHA-0654 & Viseu, P (A) & Favada pinto & $\mathrm{L}$ & I & $\mathrm{S}$ & $\mathrm{R}$ & $\mathrm{P}$ & $\mathrm{S}$ & 9.0 & 7.6 & $\mathrm{R}$ & $\mathrm{N}$ \\
\hline PHA-0655 & Viseu, P (A) & Sargaço & $\mathrm{L}$ & I & $\mathrm{S}$ & $\mathrm{S}$ & $\mathrm{S}$ & $\mathrm{S}$ & 8.8 & 6.5 & $\mathrm{R}$ & $\mathrm{N}$ \\
\hline PHA-0663 & Vila Real, P (MA) & Mulatinho & M & III & $\mathrm{S}$ & $\mathrm{I}$ & $\mathrm{V}$ & $\mathrm{S}$ & 8.8 & 6.0 & $\mathrm{R}$ & $\mathrm{N}$ \\
\hline PHA-0678 & Vila Real, P (MA) & Small red & $\mathrm{S}$ & II & $\mathrm{S}$ & $\mathrm{S}$ & $\mathrm{R}$ & $\mathrm{P}$ & 9.0 & 7.0 & $\mathrm{~S}$ & $\mathrm{~S}$ \\
\hline PHA-0706 & Asturias, S (A) & Favada & $\mathrm{L}$ & IV & $\mathrm{S}$ & $\mathrm{R}$ & $\mathrm{R}$ & $\mathrm{S}$ & 9.0 & 7.6 & $\mathrm{R}$ & $\mathrm{N}$ \\
\hline PHA-0917 & Galicia, S (I) & Favada & $\mathrm{L}$ & IV & $\mathrm{S}$ & $\mathrm{V}$ & $\mathrm{R}$ & $\mathrm{S}$ & 9.0 & 5.6 & $\mathrm{~S}$ & $\mathrm{~S}$ \\
\hline Mean & & & & & & & & & 8.8 & 6.8 & & \\
\hline $\operatorname{LSD}(P<0$ & & & & & & & & & 0.7 & 1.1 & & \\
\hline
\end{tabular}

${ }^{\mathrm{z}} \mathrm{S}=$ Spain, $\mathrm{P}=$ Portugal; $\mathrm{A}=$ Andean gene pool, $\mathrm{MA}=$ Midde American , $\mathrm{I}=$ intermediate.

${ }^{y}$ Seed size (hence weight): $\mathrm{S}=$ small, $<25 \mathrm{~g} / 100$ seeds; $\mathrm{M}=$ medium, 25 to $40 \mathrm{~g} / 100$ seeds; and $\mathrm{L}=1$ large, $>40 \mathrm{~g} / 100 \mathrm{seeds}$

${ }^{x} \mathrm{I}=$ determinate upright, II = indeterminate upright, III = indeterminate prostrate and IV $=$ indeterminate strong climbing.

${ }^{\mathrm{w}} \mathrm{S}=$ susceptible (extended lesions), $\mathrm{I}=$ intermediate (venal lesions), $\mathrm{R}=$ resistant (without symptoms), $\mathrm{V}=\mathrm{variable}(\mathrm{mixture}$ of different symptoms).

${ }^{v} \mathrm{~S}=$ susceptible (large pustules), $\mathrm{P}=$ small pustules, $\mathrm{N}=$ necrotic pustules, $\mathrm{R}=$ resistant (without symptoms), $\mathrm{V}=\mathrm{variable}$ (mixture of different symptoms).

uScale from 1 (without symptoms) to 9 (extended lesions), where scores $<4=$ resistant, 4 to $6=$ intermediate, and $>6=$ susceptible.

${ }^{\mathrm{t}} \mathrm{S}=$ susceptible (common mosaic symptoms), $\mathrm{R}=$ resistant (without symptoms), $\mathrm{N}=$ top necrosis, $\mathrm{V}=\mathrm{variable}$ (mixture of different symptoms). 
and if any one is nonallelic to nine known loci (Kelly and Vallejo 2004). This is important because out of nine resistance genes only $\mathrm{Co}-1$ is of A origin.

Rust is not currently a main constraint to bean production in the Iberian Peninsula although humid conditions that favor the disease occur. Nonetheless, evaluation of the Iberian core collection for rust was considered important for the future use. Thirteen accessions were resistant to the A rust pathogen race 38 , whereas two showed a similar reaction to the MA race 53. Those that may merit mention include PHA-0706 and PHA-0917 in the large white favada market class, PHA-0252 in the canellini class and PHA-0471 in a small white class. Furthermore, genotyping these resistances and determining their relationships with nearly a dozen known rust resistance genes (Pastor-Corrales 2003) may be warranted for their appropriate deployments.

All accessions in the core collection showed a highly susceptible reaction to $\mathrm{CBB}$ with a disease score of 7.8 or higher and an average of 8.8. Singh and Muñoz (1999) found only a low level of resistance in a handful of accessions among several thousand from around the world. Use of highly resistant exotic germplasm (Scott and Michaels, 1992) would be essential for development of resistant cultivars for northern and central Spain where CBB is often very severe.

One accession, PHA-0247, had the lowest HB score (a score of 3.3 on a 1 to 9 scale). Asensio (1995) did not find any accession resistant to the race 1 or 2 of $\mathrm{HB}$ pathogen in germplasm from northern and central Spain. PHA-0247 has an indeterminate growth habit and small black oval seeds of the chicho negro or black turtle market class. This seed type is highly appreciated by consumers in northern Spain for traditional recipes. PHA-0247 is well adapted to the Iberian Peninsula; therefore, it could be useful for introgression of HB resistance in other popular cultivars.

A relatively high proportion of accessions susceptible to BCMV and BCMNV in this study is in accordance with previous reports by Sáiz et al. (1995) and Santalla et al (2005). Nonetheless, a top necrotic reaction to the BCMNV strain NL-3K, that indicated the presence of the $I$ resistance allele for BCMV (Drijfhout 1978), appeared in 10 accessions. PHA-0274 (dark garbanzo) and PHA-0573 (pinto) had mixtures of both symptomless and top necrotic plants suggesting the presence of recessive and dominant resistance genes within these accessions. Nonetheless, accessions uniformly resistant to $\mathrm{BCMV}$ and possessing desirable seed types such as PHA-0565 (red caparron), PHA-0654 (favada pinto) and PHA-0706 (favada) could be further tested for possible release as new cultivars in areas where these types are preferred. However, before using any of the BCMV resistant accessions in breeding programs it may be advisable to determine their linkage relationship with the undesirable $B$ allele affecting the hilum region and seed coat color darkening. The most widely used dominant $I$ allele found in the Central American black bean landraces such as Jamapa, Porrillo Sintetico, and
Turrialba is tightly linked with the $B$ allele. It is extremely difficult to introgress that resistance into the desirable beige, cranberry, pinto, red and red mottled market classes.

Common bean germplasm from the Iberian Peninsula is recognized as a source of unique large and extra-large seeded forms of exceptional culinary qualities and high market value. These include the white seeded types faba (favada), riñón (white kidney), ganxet (hook), and planchada (large great northern) (Santalla et al., 2001). Cultivars resistant to major diseases are required for these market classes for areas with a high disease incidence. Thus, adapted landraces resistant to ANT, rust, $\mathrm{HB}$ and/or BCMV/BCMNV in the Iberian core collection should be very valuable for breeding and genetics of large-seeded Andean beans in Spain, Europe and elsewhere. Furthermore, PHA-0706 with its extra-large white favada type seeds was resistant to ANT, rust and BCMV. These disease resistances in largeseeded Andean cultivars and landraces are not known. Thus, PHA-0706 should be further evaluated for potential cultivar release. The large-seeded great northern landrace PHA0399 displayed acceptable scores for rust, ANT and HB. This landrace may also merit attention due to its probably intermediate characteristics between the A and the MA common bean gene pools as a bridging-parent for inter-gene pool introgression of useful alleles.

\section{Literature Cited}

Asensio, C. 1995. Bacteriosis de judías en Castilla y León: identificación de la variación patogénica de Pseudomonas syringae pv. phaseolicola y factores que influyen en su desarrollo. Estudio de la herencia de la resistencia a la raza $1 \mathrm{de}$ P.s. pv. phaseolicola. $\mathrm{PhD}$ thesis. Univ.León, León, Spain.

Casañas, F., L. Bosch, M. Pujolà, M., E. Sánchez, X. Sorribas, M. Baldi, and F. Nuez. 1999. Characteristics of a common bean landrace (Phaseolus vulgaris $\mathrm{L}$.) of great culinary value and selection of a commercial inbred line. J. Sci. Food Agr. 79:693-698.

Drijfhout, E. 1978. Genetic interaction between Phaseolus vulgaris and bean common mosaic virus with implications for strain identification and breeding for resistance. Agr. Res. Rpt. 872:98. Centre for Agr. Publ. Doc., Wageningen, The Netherlands.

Ferreira J.J., C. Rodríguez, A. Pañeda, and R. Giráldez. 2003. Evaluation of Phaseolus vulgaris germplasm for resistance to five anthracnose races isolated in northern Spain. Annu. Rpt. Bean Improv. Coop. 46:171-172.

Geissen, A.C. and A.V. Steenbergen. 1957. A new method of testing beans for anthracnose. Euphytica 6:90-93.

Gil, J. and A. M. De Ron. 1992. Variation in Phaseolus vulgaris in the northwest of the Iberian Peninsula. Plant Breed. 109:313-319.

Kelly, J.D. and V.A. Vallejo. 2004. A comprehensive review of the major genes conditioning resistance to anthracnose in common bean. HortScience 39:1196-1207.

Monteagudo,A.B. 2004. Selección de líneas puras de judía común (Phaseolus vulgaris L.) de cualidades mejoradas y con resistencia genética a enfermedades. PhD thesis. Univ. Santiago de Compostela, Santiago de Compostela, Spain.

Pastor-Corrales, M.A. 2003. Sources, genes for resistance, and pedigree of 52 rust amd mosaic resistant dry bean germplasm lines released by the USDABeltsville bean project in collaboration with the Michigan, Nebraska and North Dakota Agricultural Experiment Stations. Annu. Rpt. Bean Improv. Coop. 46:235-241.

Pastor-Corrales, M.A., M.M. Otoya, A. Molina, and S.P. Singh. 1995. Resistance to Colletotrichum limdemuthianum isolates from Middle America and Andean South America in different common bean races. Plant Dis. 79:63-67.

Rodiño,A.P.,A.B.Monteagudo, M. Santalla, andA.M. De Ron. 2001a. Naming and release of"Judía Peregrina", "Alubia de Enfesta", "Garbanzo Grande de Tuy", "Garbanzo Capelán" and "Mourisca", five new breeding pure lines from Spain. Annu. Rpt. Bean Improv. Coop. 44:191-192.

Rodiño, A.P., M. Santalla, I. Montero, P.A. Casquero, and A.M. De Ron. 2001b. Diversity in common bean (Phaseolus vulgaris L.) germplasm from Portugal. Genet. Resour. Crop Evol. 48:409-417.

Rodiño, A.P., M. Santalla, A.M. De Ron, and S.P. Singh. 2003. A core collection of common bean from the Iberian Peninsula. Euphytica 131:165-173.

Sáiz, M., C. De Blas, G. Carazo, J. Fresno, J. Romero, and S. Castro. 1995. Incidence and characterisation of bean common mosaic virus isolates in Spain bean fields. Plant Dis. 79:79-81.

Sandlin, C.M., J.R. Steadman, C.M. Araya, and D.P. Coyne. 1999. Isolates of Uromyces appendiculatus with specific virulence to landraces of Phaseolus vulgaris of Andean origin. Plant Dis. 83:108-113.

Santalla, M., A.M. De Ron, and O. Voysest. 2001. European bean market classes, p. 79-94. In: M. Amurrio, M. Santalla, and A.M. De Ron (eds.). Catalogue of bean genetic resources, MBG-CSICPHASELIEU, Fundación Barrié de la Maza, Pontevedra, Spain.

Santalla, M., A.P. Rodiño, and A.M. De Ron. 2002. Allozyme evidence supporting southwestern Europe as a secondary center of genetic diversity for the common bean. Theor. Appl. Genet. 104:934-944.

Santalla, M.,A.M. González, M., Lema, A.P. Rodiño, A.B., Monteagudo, and A.M. De Ron. 2005. Improvement of large-seeded common bean cultivars under sustainable cropping systems in Spain. Euphytica 142:85-95

Scott, M.E. and T.E. Michaels. 1992. Xanthomonas resistance of Phaseolus interspecific cross selections confirmed by field performance. HortScience 27:348-350

Simon, C.J. and R.H.Hannan. 1995. Development and use of core subsets of cool-season food legume germplasm collections. HortScience 30:907

Singh, S.P. and C.G. Muñoz. 1999. Resistance to common bacterial blight among Phaseolus species and common bean improvement. Crop Sci. 39:80-89.

Stavely, J.R. 1983. A rapid technique for inoculation of Phaseolus vulgaris with multiple pathotypes of Uromyces phaseoli. Phytopathology 73:676-679.

Strausbaugh, C.A., J.R. Myers, R.L. Forster, and P.E. McClean. 1999. Bc-1 and $b c-u$ two loci controlling bean common mosaic virus resistance in common bean are linked. J. Amer. Soc. Hort. Sci. 124:644-648.

van Schoonhoven, A. and M.A. Pastor-Corrales. 1987. Standard system for the evaluation of bean germplasm. Centro Internacional de Agricultura Tropical (CIAT), Cali, Colombia.

Willet, W.C., F. Sacks, T. Trichopoulou, G. Drescher, A. Ferro-Luzzi, F. Helsing, and D. Trichopoulos. 1995. Mediterranean diet pyramid: a cultural model for healthy eating. Amer. J. Clin. Nutr. 61:1402-1406. 